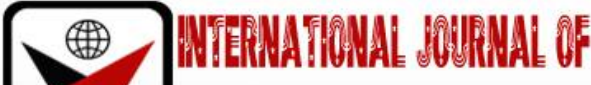

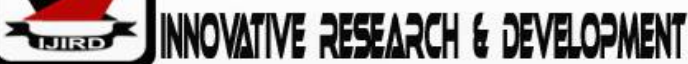

ISSN 2278-0211 (Online)

\section{Overview of the Laws and Practice of Arbitration in Nigeria: From Preliminaries to Award}

Tochukwu Micheal Benedicth
Legal Adviser, Department of Legal Unit,
Institute of Management and Technology (IMT) Enugu, Nigeria
Dr. Obioma Chike-Okenyi
Legal Adviser, Department of Legal Unit,
Institute of Management and Technology (IMT) Enugu, Nigeria

\begin{abstract}
:
The concept of Alternative Dispute Resolution (ADR) and its relevance in administration and access to justice is widely accepted globally. It is a concept that has come to stay in determining the rights and liabilities of parties in a dispute through a win-win approach. This paper studied the concept of arbitration from the introductory part to its finality, which is the award. The preliminaries of arbitration include the definition of arbitration, basic principles of arbitration and laws governing arbitration process in Nigeria. It studied further the different mode of appointment of arbitrators, the nexus between arbitration and the court. It recommended that arbitral process does not deprive lawyers or legal practitioners of revenue as erroneously inferred. It recommended also that practitioners are to build the capacity of study and research in this area and equip itself of the basics and skills of arbitration practice.
\end{abstract}

Keywords: Arbitration, alternative dispute resolution (ADR), Justice

\section{Introduction}

Dispute or conflict is part and parcel of human life, and will always be. Disputes arise in human relationships be it commercial, industrial or traditional. But they have to be resolved in such a manner as to ensure peace, stability, harmony and progress in the society. ${ }^{1}$

The elementary understanding of rules and regulations proffer some level of orderliness in human relationship. It is a notorious fact, especially for the legal minds that what gives these rules and regulations some enforcement coloration is its legislative connotation. In other words where rules are not garnished with legislative flavor, it is a mere guideline that can be thwarted by the will of the might.

The above was the position of the practice of arbitration in the years back when our fore fathers practiced a system where a neutral third party, usually the elders are called upon to adjudicate over a conflict and hand down a decision which is binding on the parties. In place of resorting to self-help and violent means of settling disputes in primitive times, African communities had developed mediatory and arbitrary dispute resolution mechanisms. ${ }^{2}$ This assertion was supported by Oguntade JCA (as he then was) in Okpuru v. Okpanam where he stated as follows:

In the pre-colonial times and before the advent of the regular courts, our people certainly had a simple and inexpensive way of adjudicating over disputes between them. They referred them to elders or a body set up for that purpose. The practice has over the years become strongly embedded in the system that they survive today as custom.

As the society advanced in exposure and globalization, it became necessary that a formal system, different from the normal court/litigation process be developed and codified to give access to justice a chance. The traditional means of settling dispute in Nigeria is through recourse to law suit or simply put, litigation. Litigation is the process of carrying on a law suit ${ }^{3}$. It has been defined as a legal action including all the proceedings therein. The history of litigation has been one of adversarial dispute resolution, of a win-lose process. With this process it is rare to understand the underlying motives behind conflicts. ${ }^{4}$

Litigation by its very nature is a cause for anxiety to those concerned, whether as lawyers or as parties. This is primarily because of the uncertainties on the outcome of litigation. A judge had once told a group of lawyers that 'as a

${ }^{1}$ Edwin Obimma Ezike, 'Developing A Statutory Framework For ADR In Nigeria' [2011-2012] (10) Nig. J.R. 2

${ }^{2}$ Francis Oleghe 'The Historical Development of Modern Arbitration in Nigeria' Journal of Arbitration (vol.14, number 1,2019) 427

${ }^{3}$ ABA Gumel, 'Trends in the Adjudication of Maritime Cases: The Experience of a Trial Court Judge' (2003 (1) NJML,

${ }^{4}$ Ikenga k. E. Oraegbunam and Chienye Okafor, 'Problems of Litigation in Settlement of Maritime Disputes for Nigeria Today: The Preference for Arbitration' [2013] NAUJILJ 32. 
citizen I would fear litigation beyond anything but sickness and death'5According to him, 'it's not a matter of who wins. It's a matter of who loses less.'

The inefficiencies of litigation call for alternative ways of resolving disputes especially in commercial transactions. There are different approaches from different scholars in defining the acronym ADR. It is defined as Alternative Dispute Resolution, Appropriate Dispute Resolution, African Dispute Resolution, and Alarming Drop in Revenue. For the purpose of this discourse, we are adopting the first definition as our guide to what Arbitration represents.

\section{What Is ADR}

ADR is defined as those dispute resolution processes, which exist as alternatives to the traditional 'formal' litigation. The term ADR therefore refers to a range of processes designed to aid parties in resolving their disputes without the need for a formal judicial proceeding.

ADR spectrums include:

- Negotiation.

- Mediation

- Arbitration.

- Conciliation

- Early Neutral Evaluation

- Mini trial

- Med-Arb

- Arb-Med etc.

The term ADR therefore refers to extra-judicial dispute resolution methods designed to complement the courts and the parties in resolving disputes in a less rancorous and quickly manner than litigation. It is not a 'substitute' to litigation but only an 'aid' to litigation. It complements the judicial process by resolving disputes involving on-going relationship in any civil dispute be it commercial or family disputes.

\section{Definition of Arbitration}

It is a reference of a dispute or difference between not less than two persons for determination, after hearing both sides in a judicial manner, by a person or persons other than a court of competent jurisdiction. ${ }^{6}$

Arbitration is a fair resolution of a dispute between two or more parties by a person or persons other than by a court of law. It is the reference of a dispute by parties thereto for settlement by a person or tribunal of their own choice, rather than a court. ${ }^{7}$ The basis for arbitration is the consent of the parties to submit or refer their dispute to arbitration. The strength of arbitration lies in the enabling law that confers it with the sanction of enforcement once a final award is made. ${ }^{8}$ The meaning and nature of arbitration was laid out in Nigerian National Petroleum Corporation v. Lutin Investment Ltd \& Anor ${ }^{9}$ thus:

An arbitration is the reference of a dispute or differences between not less than two parties for determination, after hearing both sides in a judicial manner, by a person or persons other than a court of competent jurisdiction. The arbitrator who is not an umpire, has the jurisdiction to decide only what has been submitted to him by the parties for determination. If he decides something else, he will be acting outside his authority and consequently the whole proceedings will be null and void and of no effect. This will include any award he may subsequently make.

In arbitration, a party's task is to prove his case and convince the arbitral tribunal that he is right; whereas in other forms of ADR, the task is to convince or compromise with the other party since the outcome must be accepted by both parties. Thus the process and outcome are determined solely by the will of the parties. ${ }^{10}$ While an arbitrator is empowered to make a binding award, in other forms of ADR like mediation, a mediator has no power to make a binding decision. The procedure adopted in arbitration is different from that obtained in other forms of ADR. Arbitrators must act in accordance with the rules of natural justice, that is to say, they must hear both parties together and at the same time. On the other hand, mediators are free to see the parties independently and privately, and because of the duties of confidentiality, may not even disclose to one party what they have been told by the other. ${ }^{11}$

Therefore an arbitrator is that person or persons who decides the rights and liabilities of the parties in a dispute, and makes a decision called an award.

\section{Sources of Nigerian Arbitration Law}

- Statutes: Local and international/foreign statute form the single largest source of Nigerian arbitration laws. The local statutes are basically, the Arbitration and Conciliation Act ${ }^{12}$ and the Foreign Judgments (Reciprocal Enforcement) Act. Other local statutes are those that simply provide for arbitration and how it may be conducted.

\footnotetext{
5 Walker J. in an interview with C. Bagley, Boston Massachusetts, 2003 In C. Bagley, Winning Legally (Harvard Business School Press, Cambridge MA 2005)

${ }^{6}$ Halsbury's Laws of England (3rd ed. Vol 2) 2

7 F. Ajogwu, Commercial Arbitration in Nigeria: Law \& Practice (Commercial Law Development Services)2007. Pg 5

8 Ibid

${ }^{9}$ (1976) 4 UILR p89

10 ibid

11 R. Bernstein, Handbook of Arbitration Practice, (3rd edn., London: Sweet \& Maxwell, 1998), para. 11-06

12 Cap A18 LFN 2004
} 
International/Foreign statutes are the UNCITRAL Model Law, the New York Convention and the UNCITRAL Arbitration Rules.

- Common Law \& Equity

- $\quad$ Trade Usages and Custom

\section{Types of Arbitration}

Arbitration in Nigeria could be mandatory or consensual. 'Mandatory' arbitration is, for example, provided for under the Trade Dispute Act,13 whereby industrial disputes are required to be referred, in the first instance, to the Industrial Arbitration Panel (IAP) before the National Industrial Court (NIC) may be seized of jurisdiction, should the IAP not be able to resolve the dispute. Also, football disputes must be submitted in the first instance to Arbitration under the Nigerian Football Federation (NFF) Rules and Nigerian Premier League (NPL) Rules as mandated by the Federation of International Football Association (FIFA).

'Consensual' arbitration, on the other hand, arises where the parties to a contract or other transaction have drawn up an arbitration agreement or included an 'Arbitration clause' in their contract to resolve any disputes which may arise there from. This is the most common form of Arbitration.

The following are the different types of Arbitration:

- Domestic Arbitration: A domestic arbitration is arbitration on a dispute between persons doing business in the same country and where the subject matter of the arbitration is to be performed within the same country. Domestic arbitration is further categorized into Customary law arbitration, Common law arbitration and Arbitration under the Act.

- International arbitration: An international arbitration involves parties to an arbitration agreement who have their places of business in different countries, or where the subject-matter of the arbitration relates to more than one country, or where the parties expressly agree that any dispute arising from the commercial transaction shall be treated as an international arbitration. ${ }^{14}$

Both domestic and international arbitration are categorized as institutional or ad hoc arbitration. In an institutional arbitration, parties provide in their contract for the arbitration to be conducted in accordance with the procedures and rules of a named arbitration agency or institution, such as the International Chamber of Commerce (ICC) in Paris; the London Court of International Arbitration (LCIA) the American Arbitration Association (AAA), the Regional Centres for International Arbitration (RCIA) established in Cairo, Egypt; Baghdad, Iraq; Doha, Qatar, Nairobi, Kenya; and Lagos, Nigeria and the Chartered Institute of Arbitrators Nigeria trading under the name of Nigerian Institute of Chartered Arbitrators (NICArb).

Ad-hoc arbitration is where parties submit their dispute to a third party agreed upon by them and in whom they have a measure of confidence.

\section{Basic Principles of Arbitration}

\subsection{Voluntary Submission and Party Autonomy}

Voluntary submission is the basis to arbitration and it is universal to the concept of arbitration under all legal systems; it is irrelevant whether the arbitration is under statute, common law or according to customs and usages. The pivotal concept herein is the voluntariness and the word voluntary as defined by the Black's Law Dictionary is that which is 'Done by design or intention, intentional, proposed, intended or not accidental, intentionally and without coercion.' Parties to arbitration proceedings are free to make a choice on how the proceedings will be conducted. ${ }^{15}$

\subsection{Arbitrable Disputes}

Not all disputes can be submitted to arbitration. The general guide to arbitrable disputes is that such disputes must be justifiable issues triable by a civil court. Furthermore, the disputes must be capable of being compromised by accord and satisfaction, that is, they must be matters on which a person can contract or enter into agreement on terms with another person.

Disputes arising from the following transactions are arbitrable: contract, personal property, deeds of separation, inheritance, land use, partnership, companies, co-operatives, interpretation of the law and documents, among others.

On the other hand, some disputes are not arbitrable on account of express provisions of the law, illegality and public policy. Among this group of disputes are: criminal offences ${ }^{16}$, illegal contracts ${ }^{17}$, gaming and wagering contracts; and divorce petitions. Also, it should be noted that when a party admits liability of a party's claim against him, such a claim is no longer arbitrable even when the liable party fails to fulfill his obligation to the claimant ${ }^{18}$

\subsection{Confidentiality}

Arbitral proceedings by their nature are held in camera with only the parties, their counsel where applicable, witnesses and arbitrators present. Arbitrators are bound by ethics to treat all aspects of the proceedings as confidential

\footnotetext{
${ }^{13}$ Cap. T8 Laws of the Federation of Nigeria, 2004

${ }^{14}$ See section 57 Arbitration and Conciliation Act (hereinafter called ACA)

15 See article 19 UNCITRAL MODEL LAW, Section 15 of ACA

16 (R vs. Blakemore (1850) 14 Q.B. 544.)

17 (Re Bok \& Co. and Paters Rushton \& Co. (1919) 1 K.B. 491.)

18 (United World Ltd Inc. vs. M.T.S. Ltd. (1988) 10 NWLR pt 586 p. 106 at 116.)
} 
and not to be divulged to external parties except with the express authority of all the parties to the process. It is also the practice for sophisticated arbitration agreements to include a clause of confidentiality binding the parties thereto. The essence of confidentiality is particularly underscored where disputes result from matters the parties would prefer to keep off from the glare of the public, including issues such as trade secrets, patents, research and finances. Confidentiality is one of the strong selling points of arbitration, because in this aspect it contrasts with litigation which constitutionally must be conducted in public.

\section{Binding Nature of Arbitration Agreement/Clause}

All arbitration agreements, both pre-dispute agreements and agreements reached after disputes have arisen, referred to as submissions, once subscribed to, bind the subscriber and can be enforced by a court of law where a subscriber defaults to refer a matter to arbitration at the instance of the other party. A party to an agreement to arbitrate can only be let off the hook by mutual consent of all subscribers or by an order of court on grounds such as fraud, coercion, illegality and public policy.

Arbitration agreement is autonomous to the main contract ${ }^{19}$, binding and enforceable at law ${ }^{20}$. Thus, arbitration agreement is independent and autonomous of the main contract for the transaction between the parties. ${ }^{21}$. This implies that the arbitration clause is both separable and severable from the main contract between the parties with respect to the substantive transaction. Thus, even where a contract is terminated by the parties, or is void or voidable, the arbitration agreement survives on its own to govern dispute resolution between the parties.

An arbitration agreement could derive from different sources. Reference of a dispute to arbitration may be through a voluntary agreement between the parties. In other words, the parties included a clause in their contract agreement. ${ }^{22}$ It is the arbitration agreement that gives arbitrators jurisdiction to hear and determine any dispute.

\subsection{Types of arbitration Agreement}

Generally, arbitration agreements are drafted as clauses, which are inserted into other contracts governing the main transaction between or among parties which has or may lead to a dispute. Such agreements which are inserted into main transaction contracts are referred to as 'arbitration clauses'. Also, the referral to arbitration may be contained in a statute regulating the transaction between the parties. In such a case, being a prescription of statute, settlement of dispute through arbitration would be a mandatory step before resort could be had to other dispute settlement options. ${ }^{23}$

There are two main types of arbitration agreements: pre-dispute and post-dispute agreements. The pre-dispute arbitration agreements are those usually found as arbitral clauses in contracts governing transactions of parties. These pre-dispute agreements are anticipatory in nature. They make preparations for the likelihood of future differences or disputes which may arise out of transactions between or among parties. On the other hand, the post-dispute arbitration agreements are negotiated and entered into after a dispute has ensued between or among parties and this specie of agreement is often referred to as a 'submission agreement'. This is because the parties in such post-dispute agreements agree to submit their disputes for resolution by arbitration. ${ }^{24}$

\section{Appointment of Arbitrators}

The appointment of arbitrator(s) follows immediately after the service of notice of arbitration by the claimant to the respondent. Although, often in the notice of arbitration, the party serving the notice informs the other that it has appointed an arbitrator and either requests that the other party concurs to the appointment or appoint its own arbitrator, depending on the number of arbitrators stipulated in the agreement.

The arbitrator (in the case of more than one arbitrator, 'the arbitral tribunal') may be appointed by:

- Parties

- An arbitral institution, upon the authority of the parties

- An independent appointing authority

- Existing arbitrators

- Court - Article 6 (2)- (3) of the Arbitration Rules.

Parties are at liberty in their agreement to specify the number and mode of appointment of the arbitrator(s) ${ }^{25}$.Where no procedure is specified, Section 7(2) of the ACA provides that:

- In the case of an arbitration with three arbitrators, each party shall appoint one arbitrator and the two thus appointed shall appoint the third. If a party fails to appoint the arbitrator within thirty days of receipt of a request to do so by the other party or if the two arbitrators fail to agree on the third arbitrator within thirty days of their appointment, the appointment shall be made by the court on the application of any party to the arbitration agreement.

- In case of an arbitration with one arbitrator, where the parties fail to agree on the arbitrator, the appointment shall be made by the court on the application of any party to the arbitration agreement made within thirty days of such disagreement.'

\footnotetext{
19 See Article 21(2) UNCITRAL Arbitration Rules, section 12(2) ACA

20 See sections 4 \& 5 ACA

${ }^{21}$ See Article 21(2) UNCITRAL Arbitration Rules

22 Akin Ibidapo-Obe and F. Aboyomi Williams 'Arbitration in Lagos State; A Synoptic Guide ( Concept Publications Limited 2010 ) 28

23 Ibid.

${ }^{24}$ Greg. C. Nwakoby , The Law and Practice of Commercial Arbitration in Nigeria (Enugu: Snaap Press Ltd) 2014

25 See section 7 ACA generally
} 
By virtue of Section 7(4) of the Act, a decision of the court as regards appointment shall not be subject to appeal. This provision has been held to be inconsistent with a party's right of appeal under the Constitution ${ }^{26}$.

\section{The Courts and the Arbitral Process}

Parties to arbitration agreement can only refer matters of arbitration to either High Court of a State, the High Court of the Federal Capital Territory Abuja or the Federal High Court. ${ }^{27}$ However, it is important to state that, the Supreme Court of Nigeria has the original jurisdiction to entertain application for the enforcement of ICSID awards as a court of first instance. ${ }^{28}$

It must be mentioned that the jurisdiction of any of these courts to entertain arbitration matters is subject to the constitutional provisions setting out the jurisdiction of these courts in Nigeria. A court which has no jurisdiction to entertain the matter in respect of the subject matter of the arbitration cannot have jurisdiction to intervene in the matter. ${ }^{29}$

In Nigeria, the Arbitration and Conciliation Act makes provisions for the intervention of the courts in arbitral process. These occasions for intervention are namely,

- Revocation of arbitration agreement ${ }^{30}$

- Order of stay of proceedings ${ }^{31}$

- Power to appoint or remove an arbitrator ${ }^{32}$

- $\quad$ Power to order attendance of witness ${ }^{33}$

- Power to impeach award 34

- Power to recognize and enforce an award ${ }^{35}$

\section{Arbitral Awards}

An arbitral award is a determination on the merits by an arbitration tribunal in an arbitral proceeding, and is analogous to a judgement of the court. An award is given by the tribunal based on the evidence adduced before it by the parties. Where the arbitral proceeding is conducted by a sole arbitrator, the decision of the sole arbitrator becomes the award. Where the proceeding is conducted by more than one arbitrator the majority decision becomes an award unless otherwise agreed by the parties.

The parties are at liberty to settle their differences outside the arbitral tribunal and thereafter request the arbitral tribunal to record the settlement in the form of an award on the terms agreed by the parties. This is popularly referred to as consent award. ${ }^{36}$

Once the arbitral tribunal makes its final award, it becomes functus officio and ceases to have power to deal with the matter again unless for reasons set out in section 28 of the Act.

\section{Conclusion}

This discourse as rightly encapsulated is an overview or general idea of what the laws and practice of arbitration represent. We have tried to touch a little of everything about arbitration. The need to comb different areas of arbitration in this discourse is for a novice in this area to be engaged with the reality of the practice and the need to seek for further awareness or study in this area. The practice of ADR especially arbitration is inevitable if we are to move with tide in advancing for access to justice and Foreign Direct Investment. Serious minded businessmen are frustrated with the rigours and frustrations in litigation and have even questioned the efficiency of our court system. We are all implored to develop ourselves in this area and be equipped with the current tools as legal professional. Alarming Drop in Revenue (ADR) as defined mostly by legal professionals is a farce. The opposite is the case as many practitioners have testified to have made good revenue from this practice.

\section{References}

i. Aba Gumel, 'Trends in the Adjudication of Maritime Cases: The Experience of a Trial Court Judge' (2003 (1) NJML,

ii. Akin Ibidapo-Obe and F. Aboyomi Williams 'Arbitration in Lagos State; A Synoptic Guide (Concept Publications Limited 2010)

iii. C. Bagley, Winning Legally (Cambridge: Harvard Business School Press) 2005

iv. Edwin Obimma Ezike, 'Developing A Statutory Framework for ADR In Nigeria' [2011-2012] (10) Nig. J.R.

v. F. Ajogwu, Commercial Arbitration in Nigeria: Law \& Practice (Commercial Law Development Services) 2007

vi. Francis Oleghe 'The Historical Development of Modern Arbitration in Nigeria' Journal of Arbitration (vol.14, number 1,2019) 427

\footnotetext{
${ }^{26}$ (Ogunwale vs. Syrian Arab Republic (2002) 9 NWLR (Part 771) 127)

27 See section 57(1) ACA

28 See section 1 ICSID Act, Cap I 20 LFN, 2004

29 See Afocon Nig Ltd v. The Registered Trustees of Ikoyi Clubs 1938 (1996) FHCLR 371 at 372

30 Section 2 ACA

31 Section 4 \& 5 ACA

32 Section 7 ACA

33 Section 23 ACA

34 Section 29 \& 30 ACA

35 Section 31, 51 \& 54 ACA.

36 Section 25 ACA
} 
vii. Greg. C. Nwakoby, The Law and Practice of Commercial Arbitration in Nigeria (Enugu: Snaap Press Ltd) 2014

viii. Halsbury's Laws of England (3rd ed. Vol 2)

ix. Ikenga k. E. Oraegbunam and Chienye Okafor, 'Problems of Litigation in Settlement of Maritime Disputes for Nigeria Today: The Preference for Arbitration' [2013] NAUJILJ 